\title{
Profile semantyczne przyjaciela i wroga w polsko-, rosyjsko- i niemieckojęzycznym obrazie świata
}

\section{The semantic profiles of friend and enemy in the Polish, Russian and German languages}

\begin{abstract}
The article aims at reconstructing and comparing the cultural meanings contained in the concepts friend and enemy. To achieve the objective, the author referred to research methodologies elaborated by cognitive linguists. Particularly useful were those approaches which emphasize the necessity of including both the role of cognitive processes in descriptions of language and its historical, cultural and social underpinnings. In such approaches, questionnaires and surveys are accepted as sources of empirical data. In the current study, an analysis of the specific connotations attached to the concepts friend and enemy in Polish, German and Russian is performed. The obtained results allow for creating a hierarchy of the criteria that speakers of the three languages take into consideration, and for establishing significant similarities and differences between the Polish, German and Russian semantic profiles of the two concepts.
\end{abstract}

Keywords: identity, friend, enemy, picture of the world, semantic profile

Roman Gawarkiewicz, Uniwersytet Szczeciński, Szczecin - Polska, gawarrom@interia.pl, ORCID ID: https://orcid.org/0000-0002-1700-8151

Dlugoletnia przyjaźń istnieje wtedy, gdy czworo uszu nie ma problemu ze stuchem.

Kamila Kampa

Każdy z nas żyje w magii symboli i słów, które szczególnie przemawiają do naszej wyobraźni i wywołują w nas wyjątkową atencję, ponieważ ich brzmienie lub demonstrację graficzną traktujemy jako optymistyczną wykładnię świata zawierającą obietnicę i niosącą nadzieję. Jako istoty społeczne jesteśmy też zaprogramowani do porównywania się z innymi, do oceny własnej pozycji w stosunku do ludzi z naszego bliższego i dalszego otoczenia. Porównania społeczne pomagają nam orientować się, jakie miejsce zajmujemy w danym momencie zmieniającego się świata i jaką mamy pozycję w różnorodnych interakcjach naszego życia codziennego. W rezultacie opanowaliśmy umiejętność przyglądania się in- 
nym i tworzenia na tej podstawie uproszczonych sposobów wnioskowania o ich cechach dokonywanych w dwóch możliwych kierunkach - in plus albo in minus. Bardzo często o wyborze kierunku ewaluacji decydują wyobrażenia jednostki o możliwych konsekwencjach kontaktu i bliższej relacji z innymi.

Powyższa uniwersalna zdolność oparta na eksperymentowaniu z samym sobą już przed laty nazwana została przez Hansa-Georga Gadamera ludzką wykładnią świata. Pojawiający się w pracach niemieckiego badacza problem rozumienia innego człowieka i świata traktowany jest jako podstawa ludzkiej egzystencji, dla której kluczowe są możliwości wykorzystania słów-pojęć. Pisze on o tym następująco:

[...] słowa-pojęcia [...] nie są trwałymi znakami i sygnałami oznaczającymi coś jednoznacznego, ale wypływają z komunikatywnego poruszania ludzkiej wykładni świata, dokonującego się w języku, przez nią są poruszane, przemieniane i ulegają wzbogaceniu, wchodzą w nowe konteksty, zakrywają stare, na pół popadają w zapomnienie, a ożywają w nowym, zapytującym myśleniu (Gadamer 1976: 142).

Opisana w powyższych słowach dynamika była i ciągle jest obiektem fascynacji, impulsem do poszukiwań kategorii umożliwiających jej analizę i ocenę ${ }^{1}$. Myślą przewodnią leżącą u podstaw wielu prób opisów ludzi i społeczeństw, ich aktywności poznawczej i komunikacyjnej jest zmienność jako szczególna cecha naszych myśli, przekonań, odczuć i emocji ${ }^{2}$. Ta pierwsza i centralna właściwość

${ }^{1}$ Od lat jednym z najbardziej istotnych poglądów dla opisu wzajemnych dynamicznych związków między daną wspólnotą a językiem jest koncepcja Językowego Obrazu Świata. Wysiłek badawczy Wilhelma von Humboldta (powszechnie uznawanego za twórcę podstaw tej koncepcji) stał się kanonem wielu hipotez i poszukiwań metodologicznych rozwiązań badań je weryfikujących. W centrum ich uwagi stawia się pytanie o istotę JOS. Janusz Anusiewicz, znakomity polski teoretyk i badacz JOS, twierdzi, że w idei tej chodzi przede wszystkim o badanie i próby określania, ,jakie treści poznawcze, jaka wiedza i doświadczenie oraz wartościowanie ujmowanej poznawczo rzeczywistości jest zmagazynowane w języku, przezeń przenoszone i przekazywane przyszłym pokoleniom" (Anusiewicz 281-282). Analizując bogatą literaturę przedmiotu, odnajdujemy rzecz jasna odniesienia do problemów bardziej szczegółowych, odnoszących się do różnie rozumianych pojęć wchodzących w zakres JOS, o czym pisałem w monografii Komunikacja międzykulturowa a stereotypy. Polacy - Niemcy - Rosjanie (Gawarkiewicz 2011). W tym miejscu przypomnę jedynie te terminy naukowe stworzone i funkcjonujące w obszarze JOS, które wywołały szczególnie ożywione dyskusje, a mianowicie językowy i materialny obraz świata (por. np. Bartmiński 2007a vs. Kurcz 1987), językowy i tekstowy obraz świata (por. np. Puzynina vs. Pajdzińska, Tokarski), językowy i kulturowy obraz świata (por. np. Bartmiński 2007a vs. Anusiewicz, Dąbrowska, Fleischer). Jak pokazuje praktyka badawcza, te nurty opisu wzajemnie się przenikają, a ustalenie i wybór teoretycznego zaplecza oraz metodologicznego podejścia do rekonstrukcji językowego obrazu świata uzależnione są od wybranej, empirycznie zgromadzonej bazy materiałowej.

2 Pojedynczych ludzi i całe społeczeństwa charakteryzują wewnętrznie generowane zmiany, nie zawsze będące proporcjonalną reakcją na zewnętrzne czynniki i bodźce je wywołujące. Zdarza się zarówno na poziomie jednostki, jak i na poziomie całych grup społecznych, że na pierwszy rzut 
ludzkiego doświadczenia mentalnego świadczy o tym, że jest ono niepowtarzalne, jego kształtowanie się nie ma końca, w związku z czym nie ma ono postaci skończonej wiedzy. Konstatacje o subiektywnym charakterze naszych doświadczeń mentalnych uzasadniają pytanie o ich ograniczenia i teoretyczno-metodologiczne podejście do badania i opisu tego trudnego problemu. Moim zdaniem, godne uwagi i badawczo pożyteczne będzie i w tym kontekście przywołanie poglądów Gadamera, który uważa, że wszelkie doświadczenie ludzkie ograniczone jest do podporządkowanego dziejom języka i jedynie w języku jest ujawnione. Język kontynuuje filozof - „[...] jest domostwem człowieka, w którym mieszka, urządza się, spotyka siebie, w tym co odmienne [...]" (Gadamer 1992: 109).

Kluczową pozycję w konstatacji tej zajmuje osoba i pojęcia, którymi ona operuje. Wynika z niej również konieczność ciągłych badań nad wyjaśnianiem i dopełnianiem struktury pojęciowej naszego umysłu, badań, dla których otwartość i przywoływanie różnych doświadczeń stanowią raison d'être. Takie spojrzenie na problem uzasadnia zaangażowanie wysoce zróżnicowanych podejść teoretycznych i praktyk badawczych wykorzystywanych do opisu wybranego zbioru pojęć, funkcjonującego w konkretnej wspólnocie interpretujących. W badaniach interdyscyplinarnych nad aktywnością poznawczą i komunikacyjną człowieka obok psychologii poznawczej, filozofii i socjologii szczególną rolę odgrywa językoznawstwo kognitywne. Ostatnia z wymienionych dyscyplin badawczych w swoim krytycznym nastawieniu, pytając o język, pyta w istocie o strukturę pojęciową naszego umysłu. Językoznawstwo kognitywne jako wizja metodologiczna w rzeczywistości traktuje badany zbiór słów-pojęć nie jako sztywną konstrukcję, ale przeciwnie - w swojej programowej refleksji postuluje rozumienie znaczenia językowego z perspektywy następujących jego właściwości: perspektywiczność, dynamizm i płynność, nieautonomiczność, determinizm języka i doświadczania świata (Geeraerts). Taka aktualizacja opisu semantycznego staje się międzypokoleniową transmisją znaczeń, w których interpretacji kardynalną rolę odgrywa to, jak jednostka funkcjonuje w świecie w sensie poznawczym i kulturowym, jak i co czerpie z doświadczeń swojego życia w czasie podstawowym, co zapamiętuje ze zdarzeń przeszłych i wreszcie, co zalicza do kanonu niezmiennych i uniwersalnych wzorów regulujących funkcjonowanie w ramach danej wspólnoty języka i kultury. Poszukiwanie odpowiedzi na powyższe pytania jest, w moim przekonaniu, jednym z najbardziej podstawowych teoretycznych i metodologicznych

oka nieistotne przyczyny bywają impulsem do zasadniczych i raptownych zmian. Poważnym teoretycznym wyzwaniem jest określenie sposobu opisu tych procesów. Badania nad systemem sądów społecznych, na które składa się wiele elementów poznawczych i afektywnych oraz dociekania na temat związków mechanizmów regulujących zachowania jednostki z procesami zachodzącymi wewnątrz całych grup społecznych, choć uzasadniają wiele ciekawych wniosków, nie udzielają i, ze względu na ich złożoność, nie mogą udzielić jednej odpowiedzi. 
wyzwań nauk humanistycznych i społecznych, w szczególności tych dyscyplin, których podstawę stanowią analizy procesu człowieczego poznawania i wszelkich afektywnych działań oraz ich interpretacja.

Korzystając z koncepcji wypracowanych przez językoznawców nurtu kognitywnego, w szczególności tych, którzy zwracają uwagę na konieczność uwzględniania w opisie języka procesów poznawczych, a także jego historycznych, kulturowych i społecznych uwarunkowań oraz możliwości wykorzystania w tym celu m.in. eksperymentu i ankiety jako źródła materiału empirycznego (zob. Bartmiński 2007a: 35-130 i cytowana tam literatura), zdecydowałem o wyborze przedmiotu swojej analizy, a mianowicie prezentacji i porównaniu utrwalonych w języku polskim, rosyjskim i niemieckim słów-pojęć przyjaciel i wróg. We własnych poszukiwaniach najpełniej identyfikuję się z podejściem reprezentowanym przez badaczy językowego obrazu świata, dla których przejawia się on w danych językowych, a rekonstrukcję wybranego fragmentu rzeczywistości umożliwia analiza pól leksykalno-semantycznych, w których dany leksem się pojawia. W takich dociekaniach badacz, jak postuluje Jolanta Maćkiewicz, powinien swoje działania realizować w czterech etapach. Pierwszy z nich wymaga wyodrębnienia obiektów/zjawisk będących przedmiotem zainteresowania danej wspólnoty. Etap drugi polega na podaniu cech definicyjnych i konotacyjnych wybranych obiektów lub zjawisk. Na etapie trzecim należy dokonać ich uporządkowania (tzn. wyznaczyć im miejsce wśród innych obiektów), by móc, na etapie czwartym, przystąpić do ich oceny (Maćkiewicz 193-206).

Bardzo trudnym, jeśli nie najtrudniejszym, momentem opisanej wyżej strategii badawczej jest dokonanie wyboru z bogatego zestawu słów-pojęć, które, jak pisze Ryszard Tokarski, będąc „,nośnikami konkretnych treści realioznawczych, są równocześnie predystynowane do łączenia z tą treścią elementów emocjonalnych i wartościujących [...], które odnosi się do najważniejszych sfer życia ludzkiego" (Tokarski 345). Kierując się powyższym kryterium, zdecydowałem o kierunku swoich badań (prowadzonych od dwóch lat i zaplanowanych jeszcze na dwa kolejne) i postanowiłem skupić uwagę na rekonstrukcji i porównaniu semantycznych obrazów i modeli konceptualnych ukrytych za ciągami następujących polsko-, niemiecko- i rosyjskojęzycznych jednostek leksykalnych: inny, der Andere, другой; оbcy, der Fremde, чужсой; przyjaciel, Freund, дpyz; wróg, Feind, враг.

Wyodrębnienie właśnie takiego przedmiotu badań wymaga krótkiego wyjaśnienia. Badaczowi obrazów świata zawsze towarzyszyć będą wątpliwości dotyczące właściwego doboru liczby i rodzaju jego elementów, a także niepewność, czy wziął pod uwagę wszystkie dostępne możliwości interpretacji jego językowych wykładników ${ }^{3}$. Fundamentalnym punktem wyjścia było dla mnie jasne

${ }^{3}$ Problematyczność ta wynika z faktu, że koncepcja JOS ma charakter stricte semantyczny i postuluje interpretację reprezentacji mentalnych będących owocem określonych doświadczeń jed- 
określenie perspektywy świata i miejsca, jakie zajmuje w nim poszczególny człowiek ,rozpatrywany jako nosiciel kultury i dojrzały byt duchowy, człowiek działający i oceniający dzięki pełnej kontroli swego ducha oraz łączący się z bliźnimi w ich zbiorowych poczynaniach i odczuciach" (Bauman 2007: 17). Takie bycie, działanie i ocenianie to podstawa naszej egzystencji ujmowanej jako rozumienie samego siebie, innego człowieka oraz otaczającego świata, które z kolei dokonują się z wykorzystaniem znaczeń słów i pojęć utrwalonych w języku danej wspólnoty. Bycie we wspólnocie, wychowanie i edukacja w niej sprawiają, że każda jednostka podlega jej wpływom. Angażuje też wiele emocji towarzyszących zaspokojeniu naturalnego instynktu każdego człowieka, a mianowicie definiowania własnej tożsamości i poszukiwania akceptacji i zakorzenienia we wspólnocie językowo-kulturowej. Poszukiwanie tożsamości to nie pojedynczy i odosobniony przypadek. Z kwestią tą mamy do czynienia tak na poziomie jednostkowym, jak i grupowym, a jej wyrazem jest myślenie i działanie w kategoriach swojskości i obcości. Dychotomia ta jest, co oczywiste, odzwierciedlona i interpretowana w języku. To dzięki językowi bardzo emocjonalnie kategoryzujemy rzeczywistość na naszą, w której czujemy się swojsko i bezpiecznie, oraz na obcą, która wzbudza w nas uczucie lęku i zagrożenia. Kategorie swojskość i obcość mają charakter sytuacyjny, są warunkowane okolicznościami miejsca i czasu. Początkowo bezrefleksyjnie przyjmujemy przekazywany nam w domu i szkole podział na swoich i obcych, jak i doświadczenie obcego, a także postaw wobec niego. $\mathrm{Z}$ czasem każde nowe pokolenie wypracowuje swój normatywny ład regulujący funkcjonowanie danej społeczności, który wnosi pewne korekty w widzeniu świata (w tym oczywiście swojskości i obcości), niemniej jednak nie jest w stanie całkowicie odejść od utrwalonych przez tradycję ,,wzorów kulturowych życia grupowego, ponieważ posługuje się tym samym językiem - głównym nośnikiem tychże wzorów"4. Ukształtowane wyobrażenia o grupie własnej i obcej są podstawowym elementem świadomości społecznej (Tarkowska 1997: 89) i mają charakter emocjonalny (afektywne nastawienie wobec odmienności, przekonania i wyobrażenia na temat obcych), a także intelektualny (realna wiedza na temat innych i obcych grup oraz pragnienie jej zdobywania). W tak zarysowanej prze-

nostki, historii i kultury wspólnoty, w której przebiegała jej socjalizacja i jest przechowywana w jej języku. Reprezentacje te mogą być rekonstruowane na podstawie np. różnorodnych danych językowych pochodzących z systemu języka (rodzaj gramatyczny rzeczowników, frazeologia, stereotypy językowe, metonimie, pola leksykalno-semantyczne), tekstów, ankiet, badań asocjacyjnych aż po etykietę językową (por. Bartmiński 2007a, 2007b; Anusiewicz, Dąbrowska, Fleischer).

${ }^{4}$ Aktualizacje znaczeń pojęć polskojęzycznych obszernie opisano w publikacji Język - Warto$\dot{s} c i$ - Polityka (2006). Porównawczą analizę dotyczącą aktualizacji stereotypów etnicznych i systemu wyznawanych wartości u trzech grup narodowych zawierają opracowania: Gawarkiewicz 2011; Rodziewicz 2014. 
strzeni społecznego i intelektualnego ładu najsilniejsze emocje wzbudzają w nas porównania i dokonywane w ich konsekwencji oceny wszelkich bytów społecznych (narody, państwa, wspólnoty religijne, grupy zawodowe, sąsiedzi itp.). Są one jednym z kluczowych tematów debaty medialnej, przedmiotem dyskusji na wszystkich poziomach edukacji oraz życia publicznego, w szczególności politycznego. Nie może pozostać to bez wpływu na stosunek jednostki do świata, na klasyfikację otaczającej rzeczywistości wedle kryterium podobieństwa i różnicy, a także poczucie przynależności „do grupy podobnych bądź pokrewnych jednostek, wraz z którymi przeciwstawia się innym jednostkom lub grupom" (Bauman 1995: 11). Interesujących danych, uzupełniających powyższe ustalenia, dostarczyło opisane przeze mnie badanie, którego celem była analiza typowych dla ankietowanej polskiej, niemieckiej i rosyjskiej młodzieży akademickiej sposobów profilowania pojęć inny i obcy, utrwalonych w jej elementarnych mechanizmach interpretowania rzeczywistości, na które składają się tak podstawowe operacje jak wybór, uogólnienie i wartościowanie (Gawarkiewicz 2020).

W obecnym badaniu proponuję pozostanie w kontekście obrazu dwubiegunowego świata, którego ostateczny kształt zależy od sieci relacji, od więzi między jego podmiotami stanowiącymi swoistą jakość przestrzeni społecznej opartej na opozycji przyjaciel - wróg. Pytania stawiane podczas prób określenia granic owej dynamicznej przestrzeni, ścierania się sił opartych na przyjacielskich lub wrogich relacjach dotyczą zagadnień natury etycznej i moralnej. Ich autorami są przedstawiciele różnych humanistycznych i społecznych dyscyplin. Nie sposób w krótkim artykule obwarowanym ograniczeniami wydawniczymi wszystkich ich szczegółowo zreferować. Interpretacja ładu społecznego opartego na opozycji przyjaciel - wróg zajmuje ważne miejsce w rozważaniach cytowanego już wyżej Zygmunta Baumana. Przytoczę w całości ten ich fragment, który uważam za szczególnie ważny we własnych dociekaniach:

[...] opozycja przyjaciele - wrogowie wpisuje się w opozycję swoi - obcy, z jednym zastrzeżeniem: wrogowie nie są obcymi. Wrogowie są dlatego, że są przyjaciele, czyli swoi. [...] inaczej: dlatego, że są przyjaciele, są jacyś wrogowie. Wrogowie są potrzebni o tyle, o ile w przeciwstawieniu do nich przyjaciele mogą się samookreślić, mogą powiedzieć kim są, a kim nie są. [...] Wrogowie są negatywnością wobec pozytywności przyjaciół (Bauman 1995: 79).

Jednostka interpretuje opisaną dychotomię z wykorzystaniem dostępnych jej źródeł wiedzy o świecie i panujących w nim podziałach. Punktem wyjścia dla takiego opisu są utrwalone w ramach danego ładu społecznego pewne algorytmy, sposoby uproszczonego wnioskowania o cechach otaczających nas ludzi. Kierujemy się przy tym emocjami, pod wpływem których przywołujemy cały repertuar dostępnych nam charakterystyk opisujących istotę przyjaźni i wrogości z perspektywy takich ich psychologicznych atrybutów, jak m.in. poczucie bezpieczeństwa, 
zaufanie i współpraca, poczucie zagrożenia, konflikt, rywalizacja, lęk. Zatem pojęcia przyjaciela i wroga należą do sfery naszych uczuć, które, jak pisze Anna Wierzbicka, są ,pozbawione struktury - więc niewyrażalne. Uczucie to jest coś, co się czuje, a nie coś, co się przeżywa w słowach. W słowach można zapisać myśli - nie można w słowach zapisać uczuć" (Wierzbicka 30). Niewątpliwie takie postawienie problemu jest poważnym wyzwaniem dla tych językoznawców, dla których żelaznym tematem badań są emocje i ich językowe reprezentacje. Zagadnienie to od dawna jest przedmiotem dyskusji o teoretyczno-metodologicznym podejściu do opisu sposobów wyrażania uczuć i mówienia o nich. W tym miejscu nie będę jednak tej kompetentnej i obszernej dyskusji drobiazgowo relacjonował. Przywołam jedynie te ustalenia z zakresu powyższych kwestii, które uznałem za kluczowe w niniejszym opracowaniu. Istotne $\mathrm{z}$ mojego punktu widzenia było przyjęcie kilku konkretnych rozstrzygnięć definicyjnych zaproponowanych przez Stanisława Grabiasa (Grabias 254-257) i Aleksego Awdiejewa (Awdiejew 117). Grabias stwierdza, że po pierwsze, językoznawca skupiony na próbach opisu emocji $\mathrm{w}$ istocie interesuje się tylko obrazem przeżyć wewnętrznych zawartym w znakach językowych. Po drugie, jego zdaniem, emocja to typ ekspresji polegający na uzewnętrznianiu się uczuć, którymi może być wyrażenie stosunku mówiącego (mogącego się przejawiać w każdej wypowiedzi, wyrażanego lub komunikowanego) do otaczającej go rzeczywistości lub jego wewnętrznego stanu emocjonalnego. Za istotne dla badań własnych uznaję również zaproponowane przez Awdiejewa propozycje analizowania językowo wyraźnych stanów emocjonalnych z uwzględnieniem sześciu ich odniesień emotywnych: w stosunku do samego siebie, do odbiorcy, do osoby trzeciej, do stanu rzeczy dotyczącego nadawcy i jego sytuacji, do stanu rzeczy dotyczącego odbiorcy i jego sytuacji, do stanu rzeczy dotyczącego osoby trzeciej i jej sytuacji.

Dwa powyższe uzgodnienia badawcze (z konieczności przedstawione powierzchownie) uznałem za elementarne nie tylko na etapie decyzji co do przedmiotu badań i pola obserwacji, ale również co do metod zbierania materiału i analizy zgromadzonych danych. Zaproponowana i przeprowadzona w niniejszym opracowaniu językoznawcza refleksja jest próbą rekonstrukcji i porównania polsko-, rosyjsko- i niemieckojęzycznego obrazu pojęć przyjaciela i wroga. Jako bazę dla analizy porównawczej przyjąłem dane zaczerpnięte z następujących źródeł: Polski stownik asocjacyjny z suplementem (Gawarkiewicz, Pietrzyk, Rodziewicz, dalej - PSA), Русский ассоциативный словарь (Karaulov et al., dalej - PAC) oraz internetowy słownik asocjacyjny Word associations network (źródło elektroniczne, dalej - WAN).

Wszystkie z wymienionych opracowań zawierają skojarzenia słowne. U podstawy idei stworzenia tych materiałów źródłowych legło podzielane przez ich autorów przekonanie o tym, że w języku utrwalony jest opis postrzeganego 
świata, zwłaszcza w słownictwie z całym jego bogactwem znaczeń, ujawniającym przyjęte $\mathrm{w}$ danej kulturze sposoby konceptualizacji i kategoryzacji rzeczy, systemy stosowanych wartościowań, punktów widzenia oraz utrwalonych społecznie postaw wobec świata, czyli tego wszystkiego, co składa się na kognicję społeczną - „reprezentacje mentalne, jakie ludzie mają i dzielą między sobą jako członkowie grup społecznych dla oznaczenia ludzkich wyobrażeń o sytuacjach społecznych, grupach społecznych i społeczeństwie jako takim" (Duszak 63). Wymienione opracowania słownikowe różni natomiast zarówno metoda badawcza wykorzystana w celu gromadzenia zamieszczonego w nich materiału językowego, jak i sposób prezentacji wyników badań. W przypadku dwóch pierwszych pozycji wykorzystano w tym celu test asocjacyjny ${ }^{5}$ jako metodę badania skojarzeń swobodnych, a hasła zawarte w słownikach to słowa-bodźce, obok których umieszczono wszystkie słowa-reakcje, zgodnie z zasadą częstotliwości ich występowania. WAN zaś jest efektem realizacji projektu „Sieć asocjacji słownych”, w którym wykorzystano program analizujący utwory literackie (klasyczne i współczesne). Opracowane przez autora słownika kombinacje algorytmów pozwalają odnaleźć skojarzenia z wpisanym w wyszukiwarkę słowem. Są one prezentowane wedle podziału na rzeczowniki, przymiotniki i czasowniki. Użytkownik omawianego oprogramowania ma szansę oglądu struktury znaczeniowej interesującego go pojęcia oraz jego semantycznych transformacji w tekstach artystycznych. Dotychczas w ramach projektu udostępniono dane odnoszące się do siedmiu języków: angielskiego, francuskiego, hiszpańskiego, niemieckiego, portugalskiego, rosyjskiego i włoskiego.

Zaprezentowana wyżej baza materiałowa dała możliwość przeprowadzenia prezentowanej dalej analizy profili semantycznych pojęć przyjaciela i wroga i ich porównania z kilku punktów widzenia. Po pierwsze, przywołując dane zaprezentowane w PSA i PAC, składające się na semantyczne profile przyjaciela i друга oraz wroga i врага, wskażę wspólne i swoiste dla przeciętnych użytkowników języka polskiego i rosyjskiego sposoby widzenia tych składników świata, kryteriów ich wartościowania i psychospołecznych mechanizmów ich kategoryzacji. Po drugie, porównanie danych językowych PAC z uwzględnionymi w WAN danymi dotyczącymi semantycznego wyrażania pojęć друга i врага stanie się podstawą wniosków na temat tych literackich transformacji semantycznych analizowanych pojęć, które w języku przeciętnego badanego użytkownika języka rosyjskiego zostały zagubione lub są słabo widoczne. Wreszcie, po trzecie, materiał Word asso-

\footnotetext{
${ }^{5}$ Koncepcję prowadzonych na terenie m.in. Polski i Rosji eksperymentów z zastosowaniem testów asocjacyjnych szczegółowo opisuję w tekście Archeologia świadomości językowej Polaków i Rosjan. Analiza porównawcza na materiałach polskiego i rosyjskiego słownika asocjacyjnego (Gawarkiewicz 2016).
} 
ciations network pozwoli odtworzyć i porównać wyobrażenia o takich pojęciach jak друг і враг oraz Freund i Feind, ilustrowane ich różnorodnymi językowymi kreacjami spotykanymi w rosyjskich i niemieckich tekstach literackich ${ }^{6}$. Polsko-, rosyjsko- i niemieckojęzyczny leksykograficzny opis tytułowych słów wskazuje na zbieżność punktów widzenia i perspektyw przyjętych dla charakterystyki ich pól semantycznych. W trzech językach pojęciom przyjaciela i wroga przypisuje się analogiczne cechy konieczne i wystarczające (Apresjan 40) definiujące ich znaczenie $^{7}$. W swojej interpretacji profili semantycznych wybranych do analizy słów-pojęć chcę skupić uwagę czytelnika na ich cechach percepcyjnych i funkcjonalnych, czyli takich, „które wiążą się z ustalonym przez człowieka stosunkiem rzeczy do innych rzeczy i do niego samego i ludzkim wartościowaniem tych rzeczy" (Bartmiński 2007a: 77).

Przystąpię zatem do zreferowania zgromadzonego materiału badawczego (uwzględniam wszystkie reakcje, poczynając od tych charakteryzujących się najwyższymi wskaźnikami użycia - jądrowymi składnikami znaczenia, na słabych, pojedynczych konotacjach kończąc), którego celem będzie wskazanie aspektowego powiązania cech przypisywanych pojęciom przyjaciela i wroga, ustalenie liczby, kolejności oraz globalnej struktury aspektów typowych dla polsko-, rosyjsko- i niemieckojęzycznych wizji tych pojęć.

Jak wynika $z$ danych PSA i PAC, zawartość treściowa pojęć przyjaciela i дpyга w świadomości badanych grup Polaków i Rosjan sprowadza się do liczby 131 polsko- i 148 rosyjskojęzycznych ujęzykowień. Cechy przypisywane przyjacielowi tak przez respondentów polskich, jak i rosyjskich można ułożyć w dwa główne

${ }^{6}$ Przeprowadzone badanie jest więc w swej istocie również skromną próbą zabrania głosu w dyskusji na temat granic między konotacjami utrwalonymi i ustabilizowanymi w potocznym (naiwnym) a także tekstowym, poetyckim obrazie świata.

${ }^{7}$ Por.: Przyjaciel - człowiek pozostający z kimś w bliskich serdecznych stosunkach, żyjący z kimś w przyjaźni, darzony zaufaniem; człowiek okazujący komuś lub czemuś swoją sympatię, sprzyjający czemuś, zwolennik, miłośnik, protektor; kochanek. Wróg - nieprzyjaciel, napastnik; państwo będące $\mathrm{w}$ stanie wojny z innym państwem; człowiek nieprzyjaźnie usposobiony wobec kogoś, zwalczający kogoś lub coś; zacięty przeciwnik (Słownik języka polskiego PWN, t. II: 990, t. III: 706). Друг - близкий приятель, лицо, связанное с кем-н. дружбой; сторонник, защитник кого-чего-н.; вежливого или снисходительного обращения; любовник хозяйки дома. Враг - человек, борющийся за иные, противоположные интересы, противник; недоброжелатель, человек, стремящийся причинить вред; военный противник; всё, что приносит вред, неприятности, зло (Tolkovyj slovar' russkogo âzyka Ušakova, źródło elektroniczne). Freund - jmd., der einem anderen in Freundschaft verbunden ist, ihm nahe steht; männliche Person, mit der eine Frau befreundet ist, mit der sie zusammenlebt; jmd., der etwas Bestimmtes besonders schätzt; jmd., der etw. besonderes unterstützt oder fördert. Feind - jmd., dessen Verhältnis zu einer bestimmten anderen Person durch Feindschaft bestimmt ist; jmd., dessen Verhalten den Interessen einer bestimmten Gruppe von Menschen zuwiderläuft, der für diese Gruppe eine Bedrohung darstellt; Angehöriger einer feindlichen Macht, feindlicher Soldat; jmd., der etw. entschieden bekämpft (Duden 528, 576). 
zespoły, tworzące jądro znaczeniowe omawianych pojęć: dane na temat podmiotów przyjacielskich relacji i ich społecznej przestrzeni, a także charakterystyki afektów i stanów emocjonalnych oraz ich przyczyn.

Z perspektywy młodych Polaków ważnym elementem wyobrażeń o przyjacielu są przede wszystkim osobowe, rzadziej nieosobowe kategorie obiektu $(34,6 \%$ wszystkich reakcji) uwypuklające aspekt psychicznej i społecznej bliskości. W ramach tego aspektu odnotowano liczną i dość rozbudowaną sieć polskojęzycznych asocjacji. Kontekstowym rozszerzeniem i dookreśleniem są tutaj następujące rzeczowniki podawane jako synonimiczne do słowa przyjaciel. Może nim być człowiek, osoba (rzadko zwierzę lub maskotka - pies, zwierzak, miś), z którą łączą różne odcienie przyjacielskiej relacji wyrażone w znaczeniach słów: kolega, kumpel, towarzysz, koleżanka, kompan, znajomy, druh. Te generalizujące określenia podlegają konkretyzacji i dość wyraźnie zaakcentowanej identyfikacji przyjaciela w postaci nazw stopni pokrewieństwa i innych form wzajemnej uczuciowo-intymnej relacji (brat, siostra, kuzyn, mama, prawie rodzina, mą̇ं, żona, narzeczona, dziewczyna, kochanek, partner, bliski, bliska osoba, najbliższa osoba, ktoś bliski, ulubieniec) oraz w postaci zaimków dzierżawczych i stosunkowo licznych, zwykle pojedynczych antroponimów, odnoszących się (z wyjątkiem jednego) do mężczyzn (mój, nasz, Pawet, Darek, Filip, Lechu, Robert, Wojtek, Piotr, Kasia). Dla dwójki polskich respondentów bardziej istotne w tym kontekście było wskazanie nazw dwóch zawodów, które ich zdaniem, najpełniej definiują przyjaciela - psycholog i żotnierz. Społeczna przestrzeń dzielona z przyjacielem to kraj, rodzina i szkoła.

W profilu semantycznym przyjaciela uwypuklone zostały również kategorie uczuć interpretowanych w formule 'czuję' ( $9,2 \%$ wszystkich reakcji), takich jak szczęście, radość, miłość, nadzieja i poczucie bezpieczeństwa, co ilustrują następujące konotacje: szczęście, radość, miłość, lubić, spokój, bezpieczeństwo, nadzieja, ciepło. Analizując polskojęzyczne ujęzykowienia, nie można pominąć danych językowych wskazujących na wzajemność relacji i więzi z przyjacielem, opartych na uczciwości, zaufaniu, wsparciu, gotowości przyjścia z pomocą i odpowiedzialności. Odnotowano tutaj znaczną liczbę konotacji (31\% wszystkich reakcji) pozytywnie nacechowanych, skierowanych tak na nosiciela stanu, jak i obiekt, do opisania którego zostały one przywołane: zaufanie, zaufana osoba, zaufany, ufać, ufność, powiernik, sekret, bratnia dusza, pomoc, pomaga, koleżeńska pomoc, pomocna osoba, oddany, opoka, opiekun, wierność, wierny, wsparcie, zrozumienie, rozumie, oparcie, podpora, szczerość, szczery, uczciwość, trwałość, obowiązek, prawda). W ten ważny fragment obrazu przyjaciela wpisują się również konotacje (6,5\% wszystkich reakcji) obejmujące kategorię rozmowy, spotkań oraz form wspólnego spędzania czasu i zewnętrznych przejawów przyjaźni: rozmowa, szczera rozmowa, ciepło, telefon, spotkanie, bezsenność, wyjazd, koszykówka, piwo, picie piwa, polewać, słodycze, uścisk. 
Powyższy wykaz znaków emocjonalnych należy uzupełnić o konotacje podane zdecydowanie częściej pod wpływem pozytywnego (5,5\% wszystkich reakcji) niż negatywnego ( $1,8 \%$ wszystkich reakcji) wartościowania definiowanego obiektu: dobra osoba, dobra rzecz, fajny chtopak, ktoś dobry, dobry, dobro, dobre serce, dobroć, od serca, najlepszy, najważniejsze, ważny, madrość, prawda, prawdziwy, mity, skarb, ale też brak, diabel, fatszywy, hańba, oszust, zdrajca, zły. Alternatywną do powyższych heurystykę dostępności prezentuje 37 ankietowanych (7,5\% wszystkich reakcji), dla których decydujące o rozstrzygnięciu znaczenia zawartego w słowie przyjaciel było wskazanie jego przeciwieństwa - wróg. Zreferowany profil semantyczny dopełnia jedna charakterystyka odnosząca się do wyglądu zewnętrznego (gruby) oraz konotacje najprawdopodobniej podane pod wpływem popularnych sentencji, powiedzeń i tytułów znanych z kultury popularnej (1,4\% wszystkich reakcji): bieda, czas, potrzebny, od zaraz, na dobre i na złe, powietrze.

Jak nadmieniłem nieco wcześniej, podobnie zadziałał mechanizm tworzenia sieci skojarzeniowej wokół pojęcia друга. Składa się ona z aspektów analogicznych do wyżej opisanych, różni się ich hierarchią i semantycznym wypełnieniem. Na podstawie 148 rosyjskojęzycznych reakcji wywołanych omawianym w tej chwili słowem-bodźcem można stwierdzić, że pierwsze miejsce w rankingu cech składających się na jego profil semantyczny zajmują pozytywne konotacje wartościująco-oceniające. Mamy w tym przypadku do czynienia nie tylko ze wskazaniem cech idealnego przyjaciela i określeniem emocjonalnego stosunku do niego, ale też charakterystykami modelu silnych więzi przyjacielskich nawiązanych w dzieciństwie i trwających całe życie (31\% wszystkich reakcji): лучшиŭ, xороший, мильй, любимый, сердечныгй, дорогой, бесиенный, добрый, крепкий, любезный, отличный, самый лучший, умный, хороший человек, прекрасный, родной, самыий близкий человек, самый дорогой человек, единственный, настоящий, преданный, незаменимый, детства, детство, по парте, школьный, старый, первый, постоянный, на всю жизнь, навеки, навсегда, вечный, вместе, всегда, до гроба, до гробовой доски, на всю жизнь, жизни, иенность. Niezauważalną rysą na tym wyidealizowanym obrazie są konotacje nacechowane negatywnie (1,7\% wszystkich reakcji) aktywowane świadomością trudu, jaki trzeba włożyć w poszukiwanie przyjaciela i nawiązanie z nim relacji wolnych od fałszu i zakłamania (редкий, редко, ложный, липовыгй, тупой, недоверие, измена, хуже врага).

Podobnie jak w zreferowanej polskojęzycznej sieci asocjacyjnej, tak i w tym przypadku odnotowano wiele konotacji, których treściowe wypełnienie wskazuje na ważną rangę wzajemności relacji i uczuć, wspólnie wykonywanych czynności i bliskich więzi łączących z przyjacielem, opartych na uczciwości, zaufaniu, wsparciu, gotowości przyjścia z pomocą, chęci wspólnego spędzania czasu 
(24,5\% wszystkich reakcji): дружба, любовь, счастье, тепло, ульљбка, верный, верность, надежньй, надежность, доверяю, близкий, близкий по духу, близкий человек, понимание, советчик, рядом, закадычный, собутыльник, выручать, помог, помощь, защита, говорит, телефон, прогулка, письма.

Wspólnym elementem polsko- i rosyjskojęzycznego wyobrażenia o przyjacielu są również generalizujące określenia osób identyfikowanych z użyciem nazw stopni pokrewieństwa, zaimków dzierżawczych, antroponimów (17,9\% wszystkich reakcji) oraz kategorii nieosobowych. Obok osobowych klasyfikacji przyjaciela, jako człowieka w ogóle i członków rodziny w szczególności (человек, товарищ, приятель, подруга, женщина, парень, брат, товарищ и брат, и брат, мама, мальчик, любовник, мой, твой, Вовка и Славка, Таня, Надя, Юpa), i tutaj wskazano na związki ze zwierzęciem (3,4\% wszystkich reakcji - coбака, животное). W grupie kategorii bezosobowych $(0,6 \%$ wszystkich reakcji) wspólnym elementem (podanym incydentalnie, zarówno przez polskich, jak i rosyjskich ankietowanych) jest miś (коричневыцй). Młodzi Rosjanie w omawianym kontekście wskazali jeszcze na swoją więź (porównywalną do relacji przyjacielskich) z takimi przedmiotami jak: машина і песни Высоикого.

Analizowany profil semantyczny dopełniają deskrypcje przebiegające w trybie konstatacji cech przeciwstawnych ( mujące peryferyjną pozycję mniejsze lub większe semantyczne modyfikacje znanych sentencji i powiedzeń (познается в беде, оказался вдруг, друг друга $-0,5 \%$ wszystkich reakcji). Równie rzadko wskazywano (nieodnotowane w polskim profilu semantycznym przyjaciela) charakterystyki emotywne, akcentujące przyjacielski stosunek definiowanego podmiotu do osoby trzeciej i jej sytuacji ( $1,9 \%$ wszystkich reakcji - человека, семьи, зверей), a także oznaki emocji interpretowane w formule 'czuję', opisujące uczucia braku, straty lub tęsknoty (ушел, уехал, умер, погиб, покойный, нет, скука - 1,7\% wszystkich reakcji).

Interesująco przedstawia się również struktura aspektowa pojęć wroga і врага. Przeprowadzona analiza 131 asocjatów (podanych przez 490 polskich ankietowanych) zamieszczonych w PSA i 51 uwzględnionych w PAC (wskazanych przez liczbę 107 poddanych badaniom rosyjskich studentów) wykazała, że obie grupy respondentów dokonały ich semantycznego profilowania, podając cechy mieszczące się w aspekcie psychologicznym, społecznym, ideologicznym, militarnym i lokatywnym.

Biorąc pod uwagę charakterystyki podane przez polskich respondentów, stwierdzić należy, że za stosunkowo ważne rozstrzygnięcie $(9,4 \%$ wszystkich reakcji) w procesie definiowania słowa-bodźca wróg uznali oni opisanie zawartego w nim znaczenia drogą kontrastowania ze znajdującym się na przeciwległym biegunie opisem wzajemnych relacji psychospołecznych i emocjonalnych, wyrażonych w słowach przyjaciel oraz (o wiele rzadziej) sojusznik. Kluczowa dla wy- 
obrażenia o definiowanym obiekcie jest dokonana walencja jego cech i określenie afektów z emocjonalnego pola zagrożenia, lęku i nienawiści.

Jeśli chodzi o ewaluację obrazu wroga, zespół negatywnych cech deskryptorowych przeważa nad konotacjami wartościująco-oceniającymi. W obrazie wroga dość wyraźnie uwypuklono charakterystyki ukazujące go z perspektywy typowej dla niego agresywnej postawy, sprzecznej z interesami czy wartościami jednostki bądź grupy i wyzwalającej ducha rywalizacji oraz sprzyjającej konfliktom (nieprzyjaciel, przeciwnik, przeciwieństwo, rywal, intrygant, kłótnia, konflikt, wojna, walka, atak, rywalizacja, zdrajca, złoczyńca, publiczny, ojczyzna, ojczyzny - łącznie 42,2\% wszystkich reakcji). Taki specyficzny zespół cech przypisywany jest jedynie podmiotowi osobowemu (człowiek), który został jednoznacznie dookreślony jako wróg zewnętrzny lub wewnętrzny. Rozpoznanie pierwszego z nich przebiegło drogą konstatacji (jak się okazuje wciąż obecnych w świadomości Polaków) stereotypowych wyobrażeń o wrogu i jego dalszej lub bliższej lokalizacji (Niemiec, Niemcy, III Rzesza, Rosjanin, obcy, za granica, za miedza, u bram- łącznie 3,7\% wszystkich reakcji). O incydentalnych wskazaniach wroga wewnętrznego zdecydowały własne doświadczenia (w tym indywidualny światopogląd) i subiektywna ocena osobistych relacji z ludźmi lub instytucjami z najbliższego otoczenia (Iza, Janek, ja sam, sąsiad, szpital, wyktadowcy, chrześcijaństwo, diabet, szatan, piekło, wódka - łącznie 2,4\% wszystkich reakcji).

O ewaluacji wroga przesądziła jednoznacznie negatywna ocena jego postawy moralnej oraz wynikający z niej ciąg reakcji behawioralnych, w pierwszej kolejności uzewnętrznionych w postaci opisów uczuć lęku i zagrożenia, w drugiej zaś charakterystyk koniecznych działań, które te uczucia wyzwalają: zło, nienawiść, nienawidzić, zniszczyć, zabić, śmierć, zagłada, zniszczenie, ogień, klęska, strach, niebezpieczeństwo, zagrożenie, niepokój, ból, lęk, tzy, złość, gniew, niechęć, zemsta, bić, bić się, broń, bunt, obrona, okop, szabla - łącznie 31,1\% wszystkich reakcji. Podobną strukturę aspektową wroga odnotowano w modelu sieci skojarzeniowej studentów rosyjskich wywołanej słowem-bodźcem враг, na którą składa się ogólna liczba 51 różnych ujęzykowień. Na podstawie danych zamieszczonych w PAC można stwierdzić, iż modelowanie omawianego profilu semantycznego jest o wiele bardziej skonwencjonalizowane w porównaniu z zaprezentowanym wyżej polskojęzycznym profilu pojęcia wroga.

$\mathrm{W}$ analizowanym w tym momencie przypadku mamy do czynienia $\mathrm{z}$ opisem, w którym na zbliżonym poziomie preferowanego wyboru przywoływano zarówno charakterystykę z przeciwległego bieguna opozycji przyjaciel - wróg ( $\partial p y z-10,2 \%$ wszystkich reakcji), jak i podawano konotacje, za pomocą których jako podstawowy podmiot wzbudzający wrogie intencje wskazywano w pierwszej kolejności zbiorowоść (народа, народ, человечества, наш - 19,6\% wszystkich reakcji), w drugiej zaś jednostkę (мой, личный, моего детства - 13,1\% wszystkich reakcji). 
$\mathrm{Na}$ kolejnej pozycji uplasowały się wartościująco-oceniające charakterystyki z uwzględnieniem cech pejoratywnej ewaluacji postawy moralnej definiowanego obiektu, konotacji opisujących uczucia nadawcy, a także przebieg militarnej konfrontacji z wrogiem oraz zachowania w takiej sytuacji typowe i społecznie pożądane (подлеи, предатель, убийца, кровный, беспощяадный, заклятый, злейший, злой, кровавый, ружье, лютый, угроза, ненависть, опасность, ненавистный, опасныгй, война, битва, убивать, разбит, отступил - 24,3\% wszystkich reakcji).

Opisaną sieć asocjacyjną zamyka jednorazowo podana identyfikacja obiektu (США), incydentalne konotacje charakteryzujące lokalizację wroga (близко, близок) oraz, użyte na równie niskim poziomie preferowanego wyboru, fragmenty utrwalonych w świadomości rodzimych użytkowników języka rosyjskiego przysłów i powiedzeń (бежит, не спит, не дремлет).

Zrekonstruowane i porównane dotychczas polsko- i rosyjskojęzyczne obrazy oparte na materiale skojarzeniowym zgromadzonym w wyniku testów asocjacyjnych przeprowadzonych na respondentach z Polski i Rosji nie wyczerpują oczywiście dyskusji o językowo-kulturowych konotacjach przyjaciela i wroga. Przyjęta metoda aspektowego opisu profili semantycznych pozwoliła jedynie scharakteryzować potoczną interpretację tych pojęć, na którą miały wpływ indywidualne doświadczenia każdego uczestnika badań. Za celowe, ciekawe i inspirujące badawczo uważam podjęcie próby nie tyle wyczerpującej analizy porównawczej (ze względu na złożoność problemu, jak i ogrom materiału badawczego nie można tego dokonać w krótkim opracowaniu), ile odszukania wspólnych aspektów cech przypisywanych przyjacielowi i wrogowi w bazie skojarzeń udostępnianej przez WAN. W pełni zdaję sobie sprawę, że użyta przez autora słownika metoda pozyskiwania danych językowych z dzieł literackich nie została jak dotąd poddana naukowej weryfikacji (program selekcji skojarzeń RESTAPI jest chroniony prawem autorskim, a zasady jego działania nie zostały na stronach projektu upublicznione), w związku z czym nie można na jej podstawie formułować ostatecznych wniosków. Nie można też rozstrzygać o pewnych osobniczych, typowych dla danego autora wyobrażeniach o przyjacielu i wrogu. Słownik bowiem oprócz wykazu skojarzeń podzielonych na rzeczowniki, przymiotniki, czasowniki, czasami przysłówki (nie jest to lista zamknięta) nie wskazuje ani tytułów utworów literackich, z których je zaczerpnięto, ani nazwisk ich autorów. Można je zatem potraktować jedynie jako uzupełnienie wygenerowanych przez rosyjskojęzycznych uczestników testów asocjacyjnych obrazów semantycznych słów-pojęć друг і враг, zakładając, że teksty te stanowiły, czy to na etapie edukacji szkolnej, czy w wyniku indywidualnego wyboru kanonu lektur, źródło wiedzy i doświadczeń, które są lub mogą być podstawą wyobrażeń o świecie i jego elementach.

Już pierwsze spojrzenie na sieć asocjacyjną wokół pojęcia друга wygenerowaną przez RESTAPI pozwala dostrzec, że jej centrum stanowią charakterystyki 
deskryptorowe przyjaciela z punktu widzenia wzajemnych relacji opartych na bliskiej więzi, głębokich uczuciach i obustronnym zaufaniu, dzięki czemu możliwe jest pełne z nim porozumienie, nawet bez słów (przykłady asocjacji: любим, близкие, сблизиться , взаимно, тесно, привязанность, сердечный, неразрывный, любящий, единомышленник, полуслово, взаимопонимание), a także opisy ich zewnętrznych przejawów (przykłady asocjacji: объятие, сиепиться, прижиматься, целоваться, рукопожатие). Drugoplanowe pozyсje w referowanym obrazie zajmują charakterystyki odnoszące się do takich cech przyjacielskich relacji, jak wierność, niezawodność i gotowość okazywania wsparcia i niesienia pomocy (przykłady asocjacji: преданный, верный, подбадривать, выручать, советчик, соратник). Peryferie omawianego profilu semantycznego to wskazania kategorii osób, które może połączyć przyjacielska więź (przykłady asocjacji: родственник, сослуживеи, супруги, близнещ, одноклассник).

Nieco inaczej prezentuje się hierarchia aspektów wyobrażeń zwerbalizowanych wokół pojęcia Freund. Na podstawie danych zgromadzonych z wykorzystaniem wskazanego wyżej oprogramowania można stwierdzić, że w tym przypadku priorytetowe znaczenia mają dwa typy charakterystyk. Jest to, po pierwsze, cały repertuar nazw osób spokrewnionych bądź nawiązujących relacje w innej przestrzeni społecznej, jak np. szkoła czy praca (przykłady asocjacji: Verwandte, Familienangehörige, Geschäftspartner, Bekannte, Nachbar, Kollege, Mitschüler, Lehrmeister). Po drugie, są to opisy, w których szczególnie akcentowane są bliskie relacje zbudowane na wzajemnym zaufaniu, wierności, gotowości otoczenia opieką, okazywania wsparcia i niesienia pomocy (przykłady asocjacji: Vertraute, Wohltäter, Ratgeber, Helfer, treu, herzlich, hilfsbereit, Förderer, Gönner, Beschützer). W relacjonowanej sieci asocjacyjnej obraz przyjaciela uzupełniają, mające dla niego marginalne znaczenie, wskazania na możliwą intymną relację (Ex, intim, Liebhaber).

Zaskakująco silnie skonwencjonalizowane są obrazy kryjące się w znakach враг i Feind, wyjaśniane zarówno rosyjsko-, jak i niemieckojęzycznymi asocjatami zaprezentowanymi w WAN. Bardzo rozbudowane centrum sieci niemieckojęzycznej zajmują charakterystyki mieszczące się w zakresie aspektu militarno-wojennego. Odnajdujemy w nich szczegółowy opis działań wojennych, wykaz nazwy rodzajów sił zbrojnych, typów broni, jaką się one posługują, a także nazwy żołnierzy nimi walczących. Co ciekawe, nazwy te dotyczą tylko broni stosowanej w dość odległej przeszłości (przykłady asocjatów: Streitmacht, Kriegführung, Nachschub, Hinterland, Front, Späher, Taktik, Streitwagen). Centrum sieci rosyjskojęzycznej stanowią zaś charakterystyki mieszczące się, podobnie jak w powyższym przypadku, w kontekście aspektu cech opisu działań wojennych, dotyczą jednak nie nazw wszelkich możliwych ich uczestników, ale przede wszystkim ich wyniku - najczęściej zwycięstwa i rozgromienia wroga (przykłady asocjatów: полчище, конница, сразиться, крушить, побеждать, добить, разгромить, 
победить, обезоружить). Na dalszym planie obu ciągów skojarzeniowych odnajdujemy jeszcze charakterystyki wroga jako podmiotu kierowanego uczuciem nienawiści, wykorzystującego swoją siłę i przewagę, napadającego na innych, przynoszącego ze sobą zniszczenie, śmierć i zagładę (przykłady asocjatów: нeнависть, натиск, перевес, напасть, истребление, беспощадный, коварный, ненавистный, злой; Übermacht, Vernichtung, Überlegenheit, Haß, herfallen, Übermächtig, Verderben, vernichten). Obie sieci domykają asocjaty, w których zawarty jest opis jednej możliwej reakcji na zagrożenie ze strony wroga (mogące dotyczyć jednostek, jak i całych zbiorowości), a mianowicie przeciwstawienie się i obrona (przykłady asocjatów: отпор, контратака, мщение, мстить, оборонять, защищать; Gegenangriff, bekämpfen, entgegenstellen, entgegentreten, gegenübertreten, überlisten).

Zaprezentowana analiza nasuwa kilka uwag końcowych. Z porównania polsko- i rosyjskojęzycznego profilu semantycznego przyjaciela na podstawie bazy materiałowej polskiego i rosyjskiego słownika asocjacyjnego wynika, że obie grupy łączy definiowanie tego pojęcia drogą konstatacji charakterystyk odnoszących się do równości pozycji w relacjach przyjacielskich, której fundamentem jest zaufanie i uczciwość, silna emocjonalna więź, gotowość okazywania wszelkiego rodzaju wsparcia i wspólna aktywność. Zaskakującą różnicą jest tutaj obecność tylko w rosyjskojęzycznej sieci skojarzeniowej kategorii temporalnych odnoszących się do stosunkowo licznych opisów trwałości przyjacielskich więzów.

W świadomości językowej polskich i rosyjskich respondentów odnajdujemy również tożsame elementy wyobrażeń o wrogu. Składają się na nie pejoratywne charakterystyki postawy moralnej definiowanego podmiotu i podejmowanych przez niego działań, rodzących z jednej strony uczucia zagrożenia i lęku, z drugiej zaś motywujących do kontraktywności. Na peryferiach omawianego obrazu zauważalna jest jednak dość wyraźna różnica. Otóż polscy ankietowani wykazali większą skłonność do opisu zadanego im słowa-bodźca wróg z wykorzystaniem kilku zidentyfikowanych kategorii osobowych.

Ciekawe spostrzeżenia wynikają również z (na tym etapie badań bardzo ogólnego) porównania sieci asocjatów zamieszczonych we wskazanym wyżej słowniku internetowym, zgromadzonych wokół pojęć друг i Freund. Nie zaskakuje tutaj stosunkowo wysoki, choć różny dla obu sieci, poziom frekwencji kategorii emocjonalnych pozytywnie nacechowanych, wszak literatura (wszystko jedno w jakim języku wydawana), opisując relacje między przyjaciółmi, wskazuje na rozmaite ich odcienie i konteksty - od charakterystyki potęgi i trwałości (po grób) tego typu więzów i wskazania, jak wiele można dzięki nim zrobić i osiągnąć, po problemy przyjaźni fałszywej. Zastanawiać może natomiast znacznie większy udział w niemiecko- niż rosyjskojęzycznej sieci skojarzeniowej kategorii osobo- 
wych wskazujących różne przestrzenie, w których nawiązywane są przyjaźnie - od członków najbliższej rodziny poczynając, na partnerach w biznesie kończąc.

Jeśli chodzi o skojarzenia zaprezentowane w tym samym materiale źródłowym jako semantyczne opisy pojęć враг i Feind, wcześniej wskazano, że ich dominantę stanowią charakterystyki mieszczące się w ramach aspektu militarno-wojskowego. Co wydaje się dość oczywiste, biorąc pod uwagę fakt, że częstym tłem dzieł literackich jest walka z wrogiem, okupantem, najeźdźcą i dzielne stawianie mu oporu w wojnach i toczonych w czasie ich trwania bitwach. Ich opisy bywają bardzo szczegółowe, tak w zakresie prezentacji przygotowań do walki, opisu jej przebiegu, niekiedy drobiazgowej charakterystyki użytej broni, jak i głębokiej analizy psychologicznej ich uczestników, ze wskazaniem motywów ich działań, charakterystyką przyjmowanych postaw i odczuwanych emocji.

Kończąc te rozważania, chcę podkreślić powód, dla którego należy i warto wracać do podjętej w niniejszym opracowaniu problematyki oraz uzupełniać ją dzięki badaniom naukowym. Postrzeganie i doświadczanie świata wedle dychotomii swój - obcy i przyjaciel - wróg jest typowe dla wszystkich. Coraz częściej jednak spotykamy się z jej wykorzystaniem w celach propagandowych. Figury obcego i wroga ogrywają tutaj rolę kluczową. Są one podstawą do prezentacji i identyfikacji zagrożeń zarówno tkwiących wewnątrz danej wspólnoty, jak i płynących z zewnątrz. Określane dla politycznych korzyści linie podziału utrwalają stare bądź aktywizują nowe stereotypy, uprzedzenia, stygmatyzację, społeczne wykluczenie i dyskryminację. Co szczególnie ważne, dzieje się tak przy wysokim społecznym wskaźniku znajomości skutków, do których tego typu działania doprowadziły w przeszłości, wcale nie tak odległej. Coraz głośniej słyszalne w przestrzeni publicznej próby dehumanizacji innego/obcego poprzez przypisywanie mu cech negatywnych, utożsamianie go z poważnym zagrożeniem już, niestety, przyniosły swój efekt w postaci całego repertuaru pejoratywnych charakterystyk, z dużą siłą przenikających do zasobu leksykalnego przeciętnego użytkownika nie tylko języka polskiego. Uczynienie tych językowych aktualizacji przedmiotem refleksji lingwistycznej zaspokoi nie tylko ciekawość językoznawcy, szczególnie zainteresowanego i uważnie śledzącego dynamiczne zmiany zachodzące w systemie języka, ale, co równie ważne, będzie społecznie niezwykle użyteczne.

\section{Bibliografia}

Anusiewicz, Janusz. „Problematyka językowego obrazu świata w poglądach niektórych językoznawców i filozofów niemieckich XX wieku”. Językowy obraz świata. Red. Jerzy Bartmiński. Lublin, Wydawnictwo Uniwersytetu Marii Curie-Skłodowskiej, 1990, s. $277-307$. 
Anusiewicz, Janusz, Anna Dąbrowska, Michael Fleischer. „Językowy obraz świata i kultura”. Język a Kultura. T. 13: Językowy obraz świata i kultura. Red. Anna Dąbrowska, Janusz Anusiewicz. Wrocław, Wydawnictwo Uniwersytetu Wrocławskiego, 2000, s. 11-44.

Apresjan, Jurij Derenikovič. „Definiowanie znaczeń leksykalnych jako zagadnienie semantyki teoretycznej”. Semantyka i słownik. Red. Anna Wierzbicka. Wrocław, Zakład Narodowy imienia Ossolińskich, 1972, s. 39-75.

Awdiejew, Aleksy. Pragmatyczne podstawy interpretacji wypowiedzi. Kraków, Wydawnictwo Uniwersytetu Jagiellońskiego, 1987.

Bartmiński, Jerzy. Językowe podstawy obrazu świata. Lublin, Wydawnictwo Uniwersytetu Marii Curie-Skłodowskiej, 2007a.

Bartmiński, Jerzy. Stereotypy mieszkają w języku. Studia etnolingwistyczne. Lublin, Wydawnictwo Uniwersytetu Marii Curie-Skłodowskiej, 2007b.

Bartmiński, Jerzy, red. Język - Wartości - Polityka. Zmiany w rozumieniu nazw wartości w okresie transformacji ustrojowej $w$ Polsce. Raport z badań empirycznych. Lublin, Wydawnictwo Uniwersytetu Marii Curie-Skłodowskiej, 2006.

Bauman, Zygmunt. Tożsamość. Rozmowy z Benedetto Vecchim. Gdańsk, Gdańskie Wydawnictwo Psychologiczne, 2007.

Bauman, Zygmunt. Wieloznaczność nowoczesna, nowoczesność wieloznaczna. Warszawa, Wydawnictwo Naukowe PWN, 1995.

Duden. Deutsches Universalwörterbuch, 4., neu bearbeitete und erweiterte Auflage, Herausgegeben von der Dudenredaktion. Mannheim-Leipzig-Zürich, Dudenverlag, 2001.

Duszak, Anna. Tekst, dyskurs, komunikacja międzykulturowa. Warszawa, Wydawnictwo Naukowe PWN, 1998.

Gadamer, Hans-Georg. Dziedzictwo Europy. Przeł. Andrzej Przyłębski. Warszawa, Wydawnictwo Spacja, 1992.

Gadamer, Hans-Georg. „Hermeneutyka”. Przeł. Bogdan Baran. Życie i Myśl, 4, 1976, s. 137-150.

Gawarkiewicz, Roman. „Archeologia świadomości językowej Polaków i Rosjan. Analiza porównawcza na materiałach polskiego i rosyjskiego słownika asocjacyjnego". Etnolingwistyka. Problemy języka i kultury, 28, 2016, s. 151-167.

Gawarkiewicz, Roman. Komunikacja międzykulturowa a stereotypy. Polacy - Niemcy - Rosjanie. Szczecin, Wydawnictwo Naukowe Uniwersytetu Szczecińskiego, 2011.

Gawarkiewicz, Roman. „Polsko-, niemiecko- i rosyjskojęzyczny obraz «innego» i «obcego». Analiza porównawcza pól asocjacyjnych”. Studia Rossica Posnaniensia, 45 (2), 2020, s. 147 161.

Gawarkiewicz, Roman, Izabela Pietrzyk, Barbara Rodziewicz. Polski stownik asocjacyjny z suplementem. Szczecin, Print Group, 2008.

Geeraerts, Dirk. „Introduction. A rough guide to Cognitive Linguistics”. Cognitive Linguistics. Basic Readings. Red. Dirk Geeraerts. Berlin-New York, Mouton de Gruyter, 2006, s. 1-28.

Grabias, Stanisław. Język w zachowaniach społecznych. Lublin, Wydawnictwo Uniwersytetu Marii Curie-Skłodowskiej, 1994.

Grzegorczykowa, Renata. „Idee kognitywizmu jako podstawa badań porównawczych w zakresie semantyki”. Etnolingwistyka. Problemy języka i kultury, 16, 2004, s. 75-84.

Karaulov, Ǔrij N. et al. Russkij associativnyj slovar'. Moskva, Izdatel'stvo AST, 2002.

Kurcz, Ida. Język a reprezentacja świata w umyśle. Warszawa, Wydawnictwo Naukowe PWN, 1987.

Maćkiewicz, Jolanta. „Wyspa - językowy obraz wycinka rzeczywistości”. Językowy obraz świata. Red. Jerzy Bartmiński. Lublin, Wydawnictwo Uniwersytetu Marii Curie-Skłodowskiej, 1999, s. 193-206. 
Pajdzińska, Anna, Ryszard Tokarski. „Językowy obraz świata - konwencja i kreacja”. Pamiętnik Literacki, 87, 4, 1996, s. 143-158.

Puzynina, Jadwiga. „Jak pracować nad językiem wartości?”. Język a kultura. T. 2: Zagadnienia leksykalne i aksjologiczne. Red. Jadwiga Puzynina, Jerzy Bartmiński. Wrocław, Wydawnictwo Uniwersytetu Wrocławskiego, 1989, s. 129-137.

Rodziewicz, Barbara. Wartości. Polacy - Niemcy - Rosjanie. Szczecin, Wydawnictwo Naukowe Uniwersytetu Szczecińskiego, 2014.

Słownik języka polskiego PWN. T. 1-3. Warszawa, Wydawnictwo Naukowe PWN, 1998.

Tarkowska, Elżbieta. „Niepewność kulturowa a stosunek do inności”. U progu wielokulturowości. Nowe oblicza społeczeństwa polskiego. Red. Marian Kempny, Alina Kapciak, Sławomir Łodziński. Warszawa, Oficyna Naukowa, 1997, s. 85-97.

Tokarski, Ryszard. „Słownictwo jako interpretacja świata”. Wspótczesny język polski. Encyklopedia kultury polskiej. T. 2. Red. Jerzy Bartmiński. Wrocław, Wydawnictwo „Wiedza o kulturze”, 1993, s. 335-362.

Tolkovyj slovar' russkogo âzyka Ušakova. Web. 14.11.2020. https://slovar.cc/rus/ushakov/389073. html.

Wierzbicka, Anna. Kocha, lubi, szanuje. Medytacje semantyczne. Warszawa, Wiedza Powszechna, 1971.

Wilmowska, Iwona. „Moralność i sprawność jako wymiary postrzegania społecznego”. Psychologia Społeczna, 4, 2009, s. 199-211.

Word associations network. Web. 14.11.2020. https://wordassociations.net/en/dictionary. 